\title{
Review Article \\ Role of Elicitors in Inducing Resistance in Plants against Pathogen Infection: A Review
}

\author{
Meenakshi Thakur and Baldev Singh Sohal \\ Department of Biochemistry, College of Basic Science and Humanities (COBSerH), Punjab Agricultural University, \\ Ludhiana 141 001, India \\ Correspondence should be addressed to Meenakshi Thakur; thakurmeenakshi94@gmail.com
}

Received 5 December 2012; Accepted 26 December 2012

Academic Editors: D. Hoja-Lukowicz, A.-M. Lambeir, and A. Matsuura

Copyright (C) 2013 M. Thakur and B. S. Sohal. This is an open access article distributed under the Creative Commons Attribution License, which permits unrestricted use, distribution, and reproduction in any medium, provided the original work is properly cited.

\begin{abstract}
Disease control is largely based on the use of fungicides, bactericides, and insecticides-chemical compounds toxic to plant invaders, causative agents, or vectors of plant diseases. However, the hazardous effect of these chemicals or their degradation products on the environment and human health strongly necessitates the search for new, harmless means of disease control. There must be some natural phenomenon of induced resistance to protect plants from disease. Elicitors are compounds, which activate chemical defense in plants. Various biosynthetic pathways are activated in treated plants depending on the compound used. Commonly tested chemical elicitors are salicylic acid, methyl salicylate, benzothiadiazole, benzoic acid, chitosan, and so forth which affect production of phenolic compounds and activation of various defense-related enzymes in plants. Their introduction into agricultural practice could minimize the scope of chemical control, thus contributing to the development of sustainable agriculture. This paper chiefly highlights the uses of elicitors aiming to draw sufficient attention of researchers to the frontier research needed in this context.
\end{abstract}

\section{Introduction}

Plants are challenged by a variety of biotic stresses like fungal, bacterial, or viral infections. This lead to a great loss to plant yield. There are various options available for the farmers to protect their crop from the disease. Some options include development of resistant cultivars, biological control, crop rotation, tillage, and chemical pesticides. Nearly all chemical pesticides or fungicides have a direct antibiotic principle. But their use at commercial level is uneconomical, application is cumbersome, and some are proved to be carcinogenic. Therefore, considerable efforts have been accomplished to devise environmental-friendly strategies for the check of plant diseases and thus to save mankind from health hazard [1].

Plants can activate separate defense pathways depending on the type of pathogen encountered [2]. Jasmonic acid (JA) and ethylene dependent responses seem to be initiated by necrotrophs, whereas salicylic acid (SA) dependent response is activated by biotrophic pathogens. The mechanisms responsible for this differential recognition and response may involve crosstalk among these three different signal transduction pathways: JA, ethylene, and SA.

The better understanding of plant signalling pathways has led to the discovery of natural and synthetic compounds called elicitors that induce similar defense responses in plants as induced by the pathogen infection [3]. Different types of elicitors have been characterized, including carbohydrate polymers, lipids, glycopeptides, and glycoproteins. In plants, a complex array of defense response is induced after detection of microorganism via recognition of elicitor molecules released during plant-pathogen interaction. Following elicitor perception, the activation of signal transduction pathways generally lead to the production of active oxygen species (AOS), phytoalexin biosynthesis, reinforcement of plant cell wall associated with phenyl propanoid compounds, deposition of callose, synthesis of defense enzymes, and the accumulation of pathogenesis-related (PR) proteins, some of which possess antimicrobial properties [4]. AOS lead to hypersensitive response (HR) [5] in plants which is a 
localized or rapid death of one or few cells at the infection site to delimit the pathogen growth. Following the activation of HR, uninfected distal parts of the plant may develop resistance to further infection, by a phenomenon known as systemic acquired resistance (SAR), which is effective against diverse pathogens, including viruses, bacteria, and fungi [6].

\section{Host Pathogen Interaction}

Resistance in plant species is often divided into host- or nonhost-specific resistance. Host-specific resistance involves interactions between specific host and pathogen genotypes, which give a pathogen race-specific resistance. Nonhost resistance, shown by a whole plant species against a specific parasite or pathogen, is the most common form of resistance in plants towards the majority of potential pathogens [7]. The biochemical changes that occur during infection are very similar in host and nonhost resistant plants [8]. Disease spreads only in susceptible plants (compatible interactions) which are unable to recognize the pathogen or respond too slowly [2].

The hypersensitive response is triggered by the plant when it recognizes a pathogen. The identification of a pathogen typically occurs when avirulence (Avr) gene products, secreted by pathogen, bind to or indirectly interact with the product of a plant resistance $(\mathrm{R})$ gene (gene for gene model). When both the R gene and corresponding Avr genes are present, recognition occur, which lead to active resistance of the plant and avirulence of the pathogen. If either Avr gene in the pathogen or $\mathrm{R}$ gene in the host is absent or is mutated, no recognition will occur and outcome will be a compatible reaction and disease [9]. As a result of putative binding of these two partners, a signal transduction cascade is activated and lead to the activation of a variety of plant defense responses. The defense responses are associated with restriction of pathogen growth. $\mathrm{R}$ gene products are highly polymorphic and many plants produce several different types of $\mathrm{R}$ gene products, enabling them to act as a receptor of Avr proteins produced by many different pathogens [7].

2.1. Hypersensitive Response (HR). Direct physiological contact between the host and infecting parasite is obviously necessary for the activation of HR. The HR was first described by Stakman [10] to describe rapid host cell death in resistant wheat plants upon infection by rust fungi. Hypersensitivity is a rapidly developing defense reaction induced in incompatible host by a plant pathogen, which results in the death of a limited number of host cells and a concomitant localization of the pathogen. Some investigators have described the $\mathrm{HR}$ as resembling the process of apoptosis, the principal manifestation of programmed cell death in many animal cell types [11]. This definition has now expanded to include defense gene expression in addition to cell death [7]. The HR is analogous to the innate immune response found in animals. HR provides resistance to biotrophic pathogens that obtain their energy from living cells [12].
2.2. Generation of Reactive Oxygen Species (ROS). The first report on the rapid generation of ROS during plantpathogen interactions was by Doke [13] in Phytophthora infestans-potato interaction. In studies involving bacteria and cell suspensions in the incompatible interaction, there are two phases of ROS production, termed as "oxidative burst". Phase 1 is rapid, transient, and nonspecific, whereas phase 2 occurs later and yields a much higher concentration of ROS [14]. This specific, biphasic response is proposed to be an important component of plant defense [15] because in compatible interactions only the first phase is induced [16]. The two distinct phases of the oxidative burst are seen only when an R gene and an Avr gene are both present, for example, with transgenic tomato plants differing only in the presence or absence of the $\mathrm{R}$ gene, Pto, and the bacterial pathogen, Pseudomonas syringae pv. tomato, with the avr gene, avrPto. This confirms that the second phase of the oxidative burst is associated with disease resistance [17]. The earlier defense responses are the opening of specific ion channels across the plasma membranes, the rapid production of AOS, such as $\mathrm{O}_{2}{ }^{-}$and $\mathrm{H}_{2} \mathrm{O}_{2}$, known as the oxidative burst or phosphorylation or dephosphorylation of specific proteins [18]. These initial reactions are the prerequisite for initiation of the signalling network that will trigger the overall defense response [19].

2.3. Sources of ROS. ROS are toxic intermediates that are generated through the sequential one electron reduction steps of molecular oxygen [20]. Various enzyme systems have been proposed as the source of ROS in plants. An NADPH oxidase system similar to that of mammalian systems or a $\mathrm{pH}$-dependent cell wall peroxidase may be two sources of oxidative burst [21]. If NADPH oxidase activity is a ROS generating system, $\mathrm{O}_{2}{ }^{-}$should be the initial product produced, however the $\mathrm{O}_{2}{ }^{-}$generated is usually rapidly dismutated to $\mathrm{H}_{2} \mathrm{O}_{2}$ via SOD. Therefore, in most systems $\mathrm{H}_{2} \mathrm{O}_{2}$ appears to be the major ROS that accumulates. Under physiological conditions, the first reduction of $\mathrm{O}_{2}$ forms the superoxide anion $\left(\mathrm{O}_{2}{ }^{-}\right)$and hydroperoxyl radical $\left(\mathrm{HO}_{2}{ }^{\circ}\right)$, the second step forms hydrogen peroxide $\left(\mathrm{H}_{2} \mathrm{O}_{2}\right)$, and the third step produces hydroxyl radical $\left(\mathrm{OH}^{\bullet}\right) \cdot \mathrm{OH}^{\bullet}$ and $\mathrm{O}_{2}{ }^{-}$possess very short half lives. Uncharged $\mathrm{H}_{2} \mathrm{O}_{2}$ is more stable, whereas $\mathrm{OH}^{\bullet}$ cannot migrate in solution and instead reacts locally, notably with molecular targets by modifying their structure and activity. $\mathrm{H}_{2} \mathrm{O}_{2}$ as well as $\mathrm{OH}^{\bullet}$ can react with polyunsaturated lipids in membranes forming lipid peroxides, which can lead to biological membrane destruction [22].

2.4. Role of ROS in Plant Disease Resistance. ROS species such as $\mathrm{O}_{2}{ }^{-}, \mathrm{OH}^{\bullet}$, and $\mathrm{H}_{2} \mathrm{O}_{2}$ are commonly produced under stress conditions and are strong oxidizing species that can rapidly attack all types of biomolecules and damage. For the protection from oxidative damage, plant cells contain both oxygen radical detoxifying enzymes such as catalase, peroxidase, and superoxide dismutase, and nonenzymatic antioxidants such as ascorbate peroxidase and glutathioneS-transferase [55]. These enzymes play a crucial role in the protection of plant cells from oxidative damage at the sites of 
enhanced ROS generation [56]. The cooperative function of these antioxidants plays an important role in scavenging ROS and maintaining the physiological redox status of organisms [57].

2.5. Systemic Acquired Resistance (SAR). Host plants can be protected against further pathogen attack if they have survived earlier infection by phytopathogenic viruses, bacteria, or fungi. It appears that the first infecting pathogen immunizes the plant against further infections by homologous pathogens, even though the plant may not carry gene determining cultivar-specific resistance. The readiness of the plant to repel subsequent pathogen attacks spread throughout the whole plant. This response is called systemic acquired resistance (SAR). The development of SAR is often associated with various cellular defense responses, such as synthesis of PR proteins, phytoalexins and accumulation of AOS, rapid alterations in cell wall, and enhanced activity of various defense related enzymes [58].

2.6. Sequence of Events Associated with the Establishment of SAR. The onset of SAR in noninfected plant organs is triggered by the phloem mobile signal which is released following pathogen infection. The signal travels throughout the plant and transduced in target tissues. Following signal transduction, resistance is maintained for several days and weeks and this is likely due to de novo gene expression. The biochemical changes that occur during SAR can be divided into two phases, that is, initiation and maintenance. Physiological changes during initiation phase may be transient and short lived, but during maintenance a quasisteady state should exist.

\section{Elicitors and Their Mode of Action}

Originally the term elicitor was used for molecules capable of inducing the production of phytoalexins, but it is now commonly used for compounds stimulating any type of plant defense [59-61]. Eventually, the induction of defense responses may lead to enhanced resistance. This broader definition of elicitors includes both substances of pathogen origin (exogenous elicitors) and compounds released from plants by the action of the pathogen (endogenous elicitors) $[59,62]$. Elicitors are classified as physical or chemical, biotic or abiotic, and complex or defined depending on their origin and molecular structure (Table 1).

Elicitors may be divided into two groups, "general elicitors" and "race specific elicitors". While general elicitors are able to trigger defense both in host and nonhost plants, race specific elicitors induce defense responses leading to disease resistance only in specific host cultivars. A complementary pair of genes in a particular pathogen race and a host cultivar determines this cultivar specific (gene-for-gene) resistance. Thus, a race specific elicitor encoded by or produced by the action of an avirulence gene present in a particular race of a pathogen will elicit resistance only in a host plant variety carrying the corresponding resistance gene. The absence of either gene product will often result in disease $[19,63-$ 67]. In contrast, general elicitors signal the presence of potential pathogens to both host and nonhost plants [61]. The nonspecific nature of general elicitors is relative, however, and some of these are only recognized by a restricted number of plants [68].

Recent studies have indicated remarkable similarities between the defense mechanisms triggered by general elicitors and the innate immunity of animals, and it is tempting to speculate that the recognition of general elicitors subsequently leads to plant innate immunity [69]. Elicitors act as signal compounds at low concentrations, providing information for the plant to trigger defense, distinguishing elicitors from toxins, which may act only at higher concentrations and/or affect the plant detrimentally without active plant metabolism [62]. Elicitor signal transduction mechanism which activates plant primary immune response is shown in Figure 1.

\section{Commercialization}

Alternatives to fungicides in plant protection have arisen with the discovery of disease resistance inducers of biotic and abiotic origins that induce a localized or systemic resistance in susceptible plants, which become resistant to subsequent infections. Depending on their efficacy, these compounds can be used in fields either alone or in combination with fungicides.

Many compounds have been commercially released in some countries as a plant health promoter of annual crops under the name Bion or Actigard [70]. The SA-dependent defense pathway can be activated by treatment of plants with chemical inducers such as benzo $(1,2,3)$-thiadiazole-7carbothioic acid-S-methyl ester (acibenzolar-S-methyl, ASM or BTH, Bion) developed as a potent SAR activators which do not only possess antimicrobial properties, but instead increase the crop resistance to diseases by activating SAR signal transduction pathways in several plant species. BTH is a chemical analogue of SA and has been used successfully to induce resistance to a wide range of diseases on field crops. The nonprotein amino acid $\beta$-aminobutyric acid (BABA) protects numerous plants against various pathogens. Several products have also been used as inducers of resistance in plants against pathogens, including chitosan [71, 72], salicylic acid analogues $[24,73,74]$, living or processed fungal products [75], and seaweed extracts [76]. Certain synthetic compounds with no direct antimicrobial effect such as 2,6dichloroisonicotinic acid (INA) and potassium salts has been reported to induce SAR in plants [77]. Table 2 shows the list of various elicitors used and their effects on different plant species.

\section{Conclusion}

The use of elicitors in crop protection and pest management is still in the very early stages of use as a new control method, and thus the current experiences come from experimental trials, and not yet from large scale agricultural use. At least the 


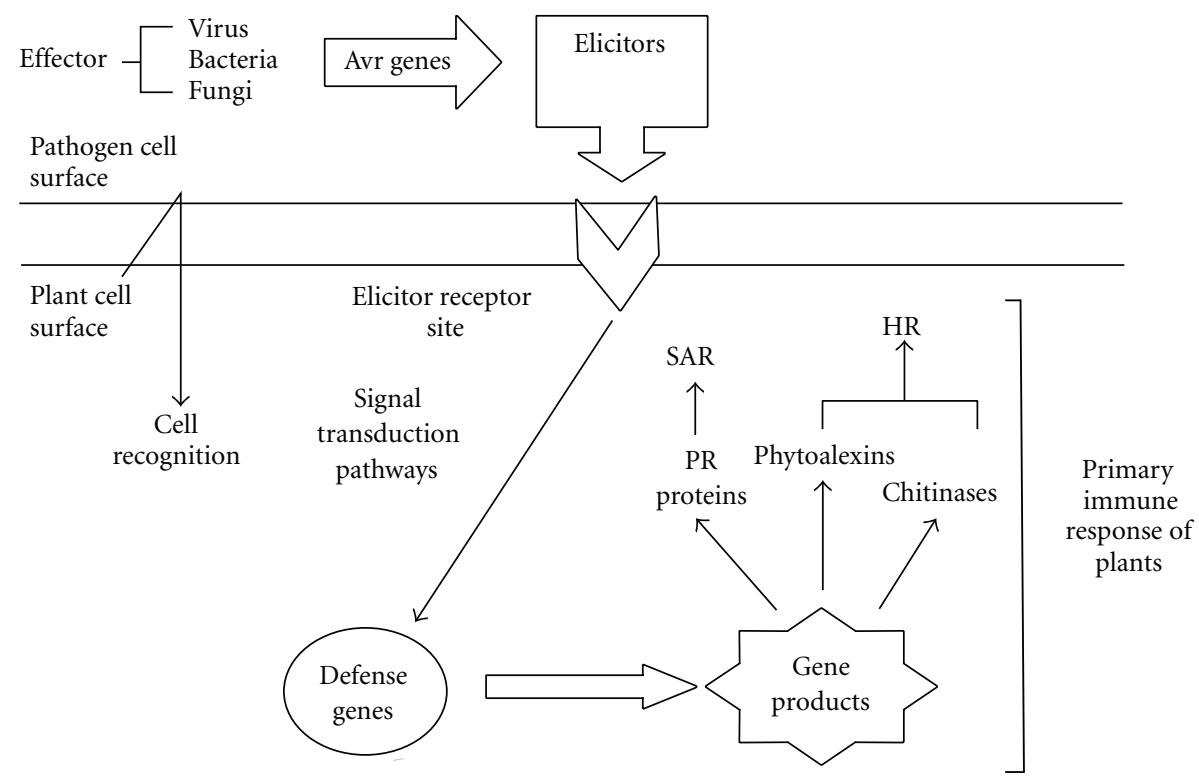

FIGURE 1: Primary immune response of plant in plant-pathogen interaction.

TABLE 1: List of various types of plant elicitors.

Type of elicitors and their examples

Physical elicitors Injury

Chemical elicitors

(1) Complex composition

Yeast cell wall, mycelia cell wall, and fungal spores
Abiotic elicitors: Metal ions

Biotic elicitors:

(2) Defined composition

(2.1) Carbohydrates

Polysaccharides:

Alginate, pectin, and chitosan

(2.2) Proteins

Peptides:

Glutathione

(2.3) Lipids

Lipopolysaccharides

(2.4) Glycoproteins

Not characterized

(2.5) Volatiles

$\mathrm{C}_{6}-\mathrm{C}_{10}$ compounds
Oligosaccharides:

Mannuronate, guluronate, mannan, and galacturonides

Proteins:

Cellulase and oligandrin following advantages of using elicitor treatments have been reported or can be expected:

(1) reduced damage from insects, fungi, pests, and herbivores,

(2) reduced environmental hazards as elicitors affect directly the crop plant, and their acute toxicity to other organisms is lower than that of pesticides,
(3) as protective agrochemicals, elicitors can be applied with the current spraying technology,

(4) elicitor treatments could be an alternative to genetically modified (GM) plants for better attraction of natural enemies of pest organisms on cultivated plants [78],

(5) elicitor-treated plants bear lower ecological risks than GM plants [79]. 


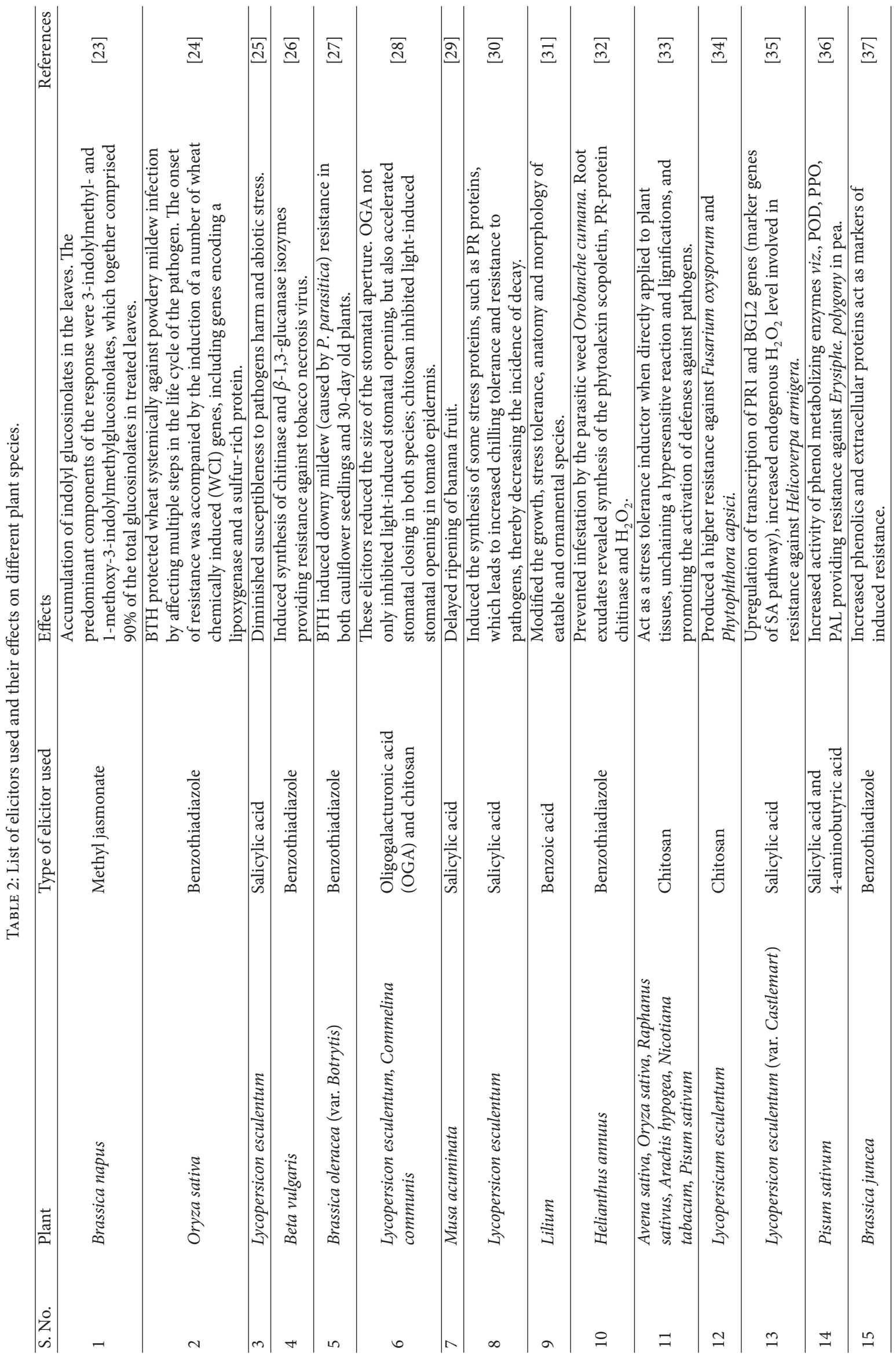




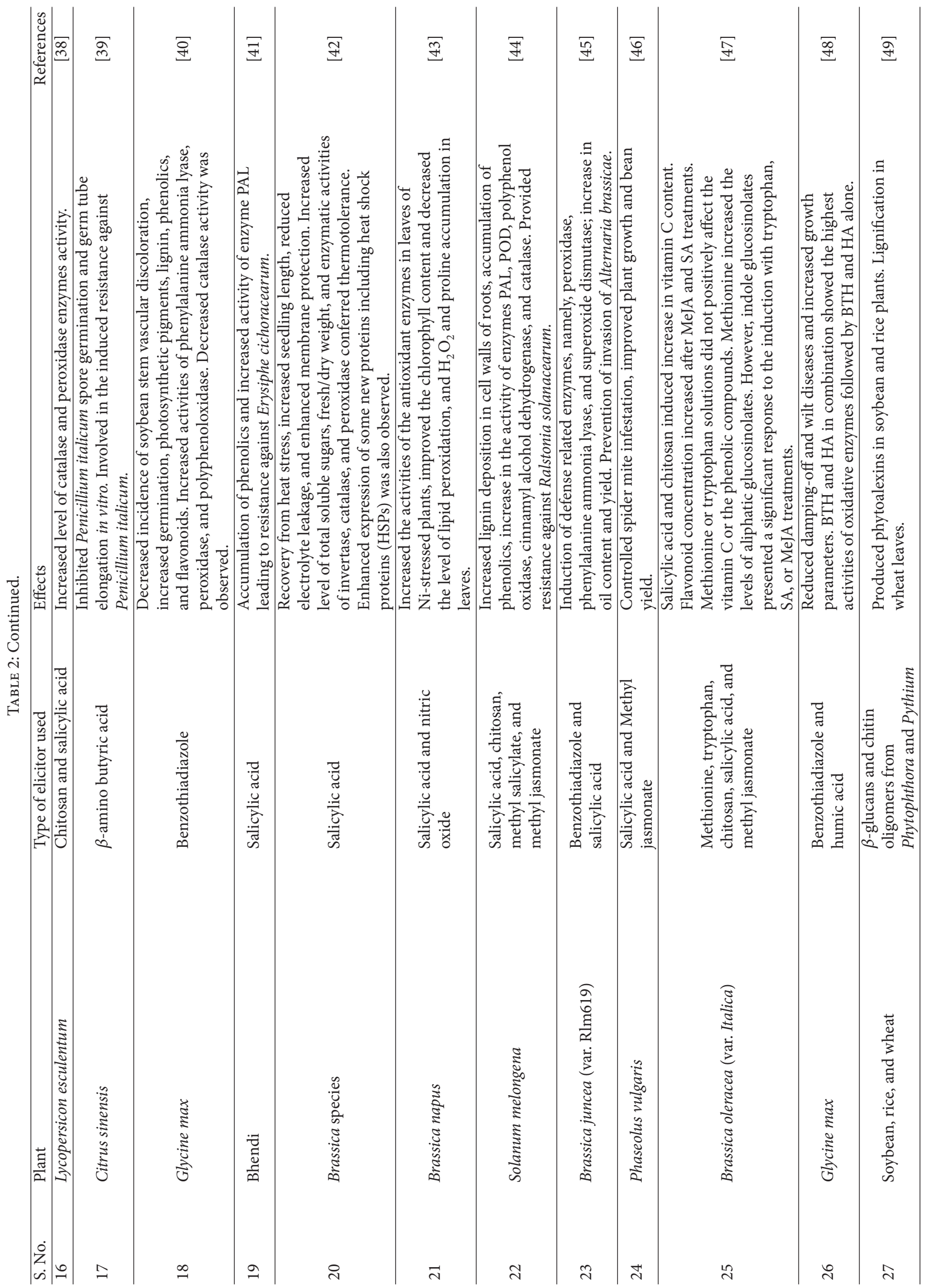




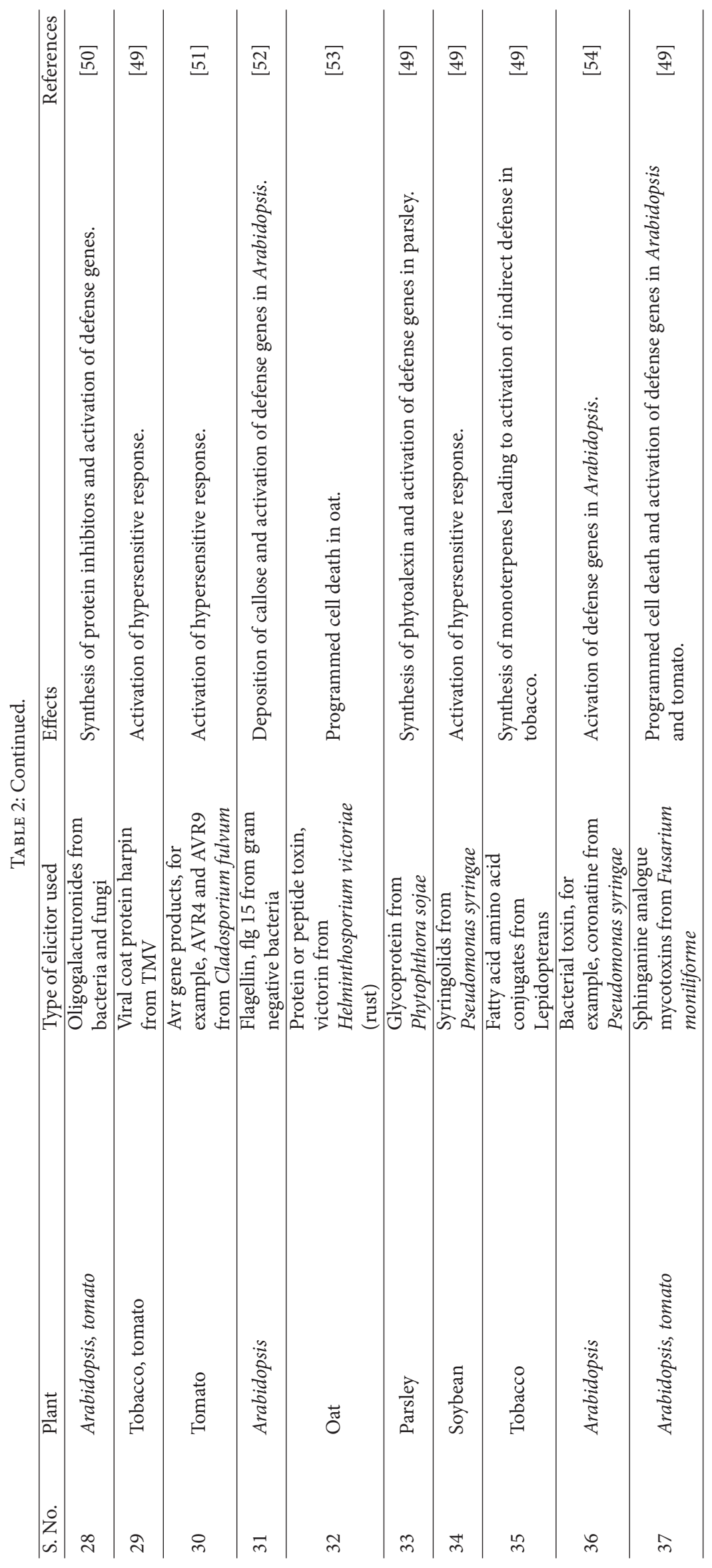




\section{References}

[1] N. G. El-Gamal, F. Abd-El-Kareem, Y. O. Fotouh, and N. S. El Mougy, "Induction of systemic resistance in potato plants against late and early blight diseases using chemical inducers under greenhouse and field conditions," Research Journal of Agriculture and Biological Sciences, vol. 3, no. 2, pp. 73-81, 2007.

[2] A. Garcia-Brugger, O. Lamotte, E. Vandelle et al., "Early signaling events induced by elicitors of plant defenses," Molecular Plant-Microbe Interactions, vol. 19, no. 7, pp. 711-724, 2006.

[3] R. Gómez-Vásquez, R. Day, H. Buschmann, S. Randles, J. R. Beeching, and R. M. Cooper, "Phenylpropanoids, phenylalanine ammonia lyase and peroxidases in elicitor-challenged cassava (Manihot esculenta) suspension cells and leaves," Annals of Botany, vol. 94, no. 1, pp. 87-97, 2004.

[4] L. C. Van Loon and E. A. Van Strien, "The families of pathogenesis-related proteins, their activities, and comparative analysis of PR-1 type proteins," Physiological and Molecular Plant Pathology, vol. 55, no. 2, pp. 85-97, 1999.

[5] G. N. Agrios, Plant Pathology, Academic Press, San Diego, Calif, USA, 3rd edition, 1988.

[6] M. Heil and R. M. Bostock, "Induced systemic resistance (ISR) against pathogens in the context of induced plant defences," Annals of Botany, vol. 89, no. 5, pp. 503-512, 2002.

[7] M. C. Heath, "Hypersensitive response-related death," Plant Molecular Biology, vol. 44, no. 3, pp. 321-334, 2000.

[8] I. E. Somssica and K. Hahlbrock, "Pathogen defence in plants-a paradigm of biological complexity," Trends in Plant Science, vol. 3, no. 3, pp. 86-90, 1998.

[9] P. J. G. M. De Wit, "Fungal avirulence genes and plant resistance genes: unraveling the molecular basis of gene-for-gene interactions," Advances in Botanical Research, vol. 21, pp. 147-185, 1995.

[10] E. C. Stakman, "Relation between Puccinia graminis and plants highly resistant to its attack," Agricultural Research, vol. 4, pp. 193-299, 1915.

[11] J. B. Morel and J. L. Dangl, "The hypersensitive response and the induction of cell death in plants," Cell Death and Differentiation, vol. 4, no. 8, pp. 671-683, 1997.

[12] J. Kumar, R. Hückelhoven, U. Beckhove, S. Nagarajan, and K. H. Kogel, "A compromised Mlo pathway affects the response of barley to the necrotrophic fungus Bipolaris sorokiniana (teleomorph: Cochliobolus sativus) and its toxins," Phytopathology, vol. 91, no. 2, pp. 127-133, 2001.

[13] N. Doke, "Involvement of superoxide anion generation in the hypersensitive response of potato tuber tissues to infection with an incompatible race of Phytophthora infestans and to the hyphal wall components," Physiological Plant Pathology, vol. 23, no. 3, pp. 345-357, 1983.

[14] C. J. Baker, N. R. O’Neill, L. D. Keepler, and E. W. Orlandi, "Early responses during plant- bacteria interactions in tobacoo cell suspensions," Phytopathology, vol. 81, pp. 1504-1507, 1991.

[15] C. Lamb and R. A. Dixon, "The oxidative burst in plant disease resistance," Annual Review of Plant Physiology and Plant Molecular Biology, vol. 48, pp. 251-275, 1997.

[16] A. Levine, R. Tenhaken, R. Dixon, and C. Lamb, " $\mathrm{H}_{2} \mathrm{O}_{2}$ from the oxidative burst orchestrates the plant hypersensitive disease resistance response," Cell, vol. 79, no. 4, pp. 583-593, 1994.

[17] S. Chandra, G. B. Martin, and P. S. Low, "The Pto kinase mediates a signaling pathway leading to the oxidative burst in tomato," Proceedings of the National Academy of Sciences of the United States of America, vol. 93, no. 23, pp. 13393-13397, 1996.
[18] U. Conrath, H. Silva, and D. F. Klessig, "Protein dephosphorylation mediates salicylic acid-induced expression of PR-1 genes in tobacco," Plant Journal, vol. 11, no. 4, pp. 747-757, 1997.

[19] K. E. Hammond-Kosack and J. D. G. Jones, "Resistance genedependent plant defense responses," The Plant Cell, vol. 8, no. 10, pp. 1773-1791, 1996.

[20] M. C. Mehdy, "Active oxygen species in plant defense against pathogens," Plant Physiology, vol. 105, no. 2, pp. 467-472, 1994.

[21] P. Wojtaszek, "Oxidative burst: an early plant response to pathogen infection," Biochemical Journal, vol. 322, no. 3, pp. 681-692, 1997.

[22] J. J. Grant and G. J. Loake, "Role of reactive oxygen intermediates and cognate redox signaling in disease resistance," Plant Physiology, vol. 124, no. 1, pp. 21-30, 2000.

[23] K. J. Doughty, G. A. Kiddle, B. J. Pye, R. M. Wallsgrove, and J. A. Pickett, "Selective induction of glucosinolates in oilseed rape leaves by methyl jasmonate," Phytochemistry, vol. 38, no. 2, pp. 347-350, 1995.

[24] J. Görlach, S. Volrath, G. Knauf-Beiter et al., "Benzothiadiazole, a novel class of inducers of systemic acquired resistance, activates gene expression and disease resistance in wheat," The Plant Cell, vol. 8, no. 4, pp. 629-643, 1996.

[25] K. Shirasu, H. Nakajima, V. K. Rajasekhar, R. A. Dixon, and C. Lamb, "Salicylic acid potentiates an agonist-dependent gain control that amplifies pathogen signals in the activation of defense mechanisms," The Plant Cell, vol. 9, no. 2, pp. 261-270, 1997.

[26] L. Burketová, M. Šindelářová, and L. Šindelář, "Benzothiadiazole as an inducer of $\beta$-1,3-glucanase and chitinase isozymes in sugar beet," Biologia Plantarum, vol. 42, no. 2, pp. 279-287, 1999.

[27] J. F. Godard, S. Ziadi, C. Monot, D. Le Corre, and D. Silué, "Benzothiadiazole (BTH) induces resistance in cauliflower (Brassica oleracea var botrytis) to downy mildew of crucifers caused by Peronospora parasitica," Crop Protection, vol. 18, no. 6, pp. 397-405, 1999.

[28] S. Lee, H. Choi, S. Suh et al., "Oligogalacturonic acid and chitosan reduce stomatal aperture by inducing the evolution of reactive oxygen species from guard cells of tomato and Commelina communis," Plant Physiology, vol. 121, no. 1, pp. 147-152, 1999.

[29] M. K. Srivastava and U. N. Dwivedi, "Delayed ripening of banana fruit by salicylic acid," Plant Science, vol. 158, no. 1-2, pp. 87-96, 2000.

[30] E. Garcia-Magallon, A. Rojas-Duarte, A. Benavides-Mendoza, F. Ramírez-Godina, and L. Bañuelos-Herrera, "Aplicación del ácido benzoico en forma foliar al cultivo de Lilium cv. Dreamland," in Memoria del XIX Congreso Nacional de Fitogenética, p. 72, Sociedad Mexicana de Fitogenética, Saltillo, Mexico, 2002.

[31] C. K. Ding, C. Y. Wang, K. C. Gross, and D. L. Smith, "Jasmonate and salicylate induce the expression of pathogenesis-relatedprotein genes and increase resistance to chilling injury in tomato fruit," Planta, vol. 214, no. 6, pp. 895-901, 2002.

[32] J. Sauerborn, H. Buschmann, K. G. Ghiasi, and K. H. Kogel, "Benzothiadiazole activates resistance in sunflower (Helianthus annuus) to the root-parasitic weed Orobanche cumana," Phytopathology, vol. 92, no. 1, pp. 59-64, 2002.

[33] I. V. Maksimov, E. A. Cherepanova, and R. M. Khairullin, “'Chitin-specific' peroxidases in plants," Biochemistry, vol. 68, no. 1, pp. 111-115, 2003. 
[34] H. Ortega-Ortíz, A. Benavides-Mendoza, A. Flores-Olivas, and A. Ledezma-Pérez, "Use of the interpolyelectrolyte complexes of poly(acrylic acid)-chitosan as inductors of tolerance against pathogenic fungi in tomato (Lycopersicon esculentum Mill. var. Floradade)," Macromolecular Bioscience, vol. 3, no. 10, pp. 566-570, 2003.

[35] J. Peng, X. Deng, J. Huang, S. Jia, X. Miao, and Y. Huang, "Role of salicylic acid in tomato defense against cotton bollworm, Helicoverpa armigera Hubner," Zeitschrift fur Naturforschung, vol. 59, no. 11-12, pp. 856-862, 2004.

[36] R. Katoch, "Effect of elicitors and E. polygoni inoculation on the activity of phenol metabolizing enzymes in garden pea (Pisum sativum L.)," Indian Journal of Agricultural Biochemistry, vol. 18, no. 2, pp. 87-91, 2005.

[37] S. Guleria and A. Kumar, "Qualitative profiling of phenols and extracellular proteins induced in mustard (Brassica juncea) in response to benzothiadiazole treatment," Journal of Cell Molecular Biology, vol. 5, pp. 51-56, 2006.

[38] H. Ortega-Ortiz, A. Benavides-Mendoza, R. MendozaVillarreal, H. Ramirez-Rodriguez, and K. D. A. Romenus, "Enzymatic activity in tomato fruits as a response to chemical elicitors," Journal of Mexican Chemical Society, vol. 51, no. 3, pp. 141-144, 2007.

[39] V. Tavallali, S. Karimi, S. Mohammadi, and S. Hojati, "Effects of $\beta$-aminobutyric acid on the induction of resistance to Penicillium italicum," World Applied Science Journal, vol. 5, no. 3, pp. 345-351, 2008.

[40] E. Nafie and M. M. Mazen, "Chemical-induced resistance against brown stem rot in soybean: the effect of benzothiadiazole," Journal of Applied Science Research, vol. 4, no. 12, pp. 2046-2064, 2008.

[41] R. Vimala and M. Suriachandraselvan, "Induced resistance in bhendi against powdery mildew by foliar application of salicylic acid," Journal of Biopesticides, vol. 2, no. 1, pp. 111-114, 2009.

[42] P. Kaur, N. Ghai, and M. K. Sangha, "Induction of thermotolerance through heat acclimation and salicylic acid in Brassica species," African Journal of Biotechnology, vol. 8, no. 4, pp. 619-625, 2009.

[43] N. Kazemi, R. A. Khavari-Nejad, H. Fahimi, S. Saadatmand, and T. Nejad-Sattari, "Effects of exogenous salicylic acid and nitric oxide on lipid peroxidation and antioxidant enzyme activities in leaves of Brassica napus L. under nickel stress," Scientia Horticulturae, vol. 126, pp. 402-407, 2010.

[44] S. Mandal, "Induction of phenolics, lignin and key defense enzymes in eggplant (Solanum melongena L.) roots in response to elicitors," African Journal of Biotechnology, vol. 9, no. 47, pp. 8038-8047, 2010.

[45] S. Sharma and B. S. Sohal, "Foliar spray of benzothiadiazole and salicylic acid on Brassica juncea var. Rlm619 to combat Alternaria blight in field trials," Crop Improvement, vol. 31, no. 1, pp. 87-92, 2010.

[46] S. Farouk and M. A. Osman, "The effect of plant defense elicitors on common bean (Phaseolus vulgaris L.) growth and yield in absence or presence of spider mite (Tetranychus urticae Koch) infestation," Journal of Stress Physiology and Biochemistry, vol. 7, no. 3, pp. 5-22, 2011.

[47] S. Pérez-Balibrea, D. A. Moreno, and C. García-Viguera, "Improving the phytochemical composition of broccoli sprouts by elicitation," Food Chemistry, vol. 129, no. 1, pp. 35-44, 2011.

[48] M. F. Abdel-Monaim, M. E. Ismail, and K. M. Morsy, "Induction of systematic resistance in soybean plants against Fusarium wilt disease by seed treatment with benzothiadiazole and humic acid," Notulae Scientia Biologicae, vol. 3, no. 2, pp. 80-89, 2011.

[49] M. Montesano, G. Brader, and E. T. Palva, "Pathogen derived elicitors: searching for receptors in plants," Molecular Plant Pathology, vol. 4, no. 1, pp. 73-79, 2003.

[50] N. Shibuya and E. Minami, "Oligosaccharide signalling for defence responses in plant," Physiological and Molecular Plant Pathology, vol. 59, no. 5, pp. 223-233, 2001.

[51] J. E. Leach and F. F. White, "Bacterial avirulence genes," Annual Review of Phytopathology, vol. 34, pp. 153-179, 1996.

[52] L. Gómez-Gómez and T. Boller, "FLS2: an LRR receptorlike kinase involved in the perception of the bacterial elicitor flagellin in Arabidopsis," Molecular Cell, vol. 5, no. 6, pp. 1003-1011, 2000.

[53] Y. Tada, S. Hata, Y. Takata, H. Nakayashiki, Y. Tosa, and S. Mayama, "Induction and signaling of an apoptotic response typified by DNA laddering in the defense response of oats to infection and elicitors," Molecular Plant-Microbe Interactions, vol. 14, no. 4, pp. 477-486, 2001.

[54] A. P. Kloek, M. L. Verbsky, S. B. Sharma et al., "Resistance to Pseudomonas syringae conferred by an Arabidopsis thaliana coronatine-insensitive (coil) mutation occurs through two distinct mechanisms," Plant Journal, vol. 26, no. 5, pp. 509-522, 2001.

[55] L. Pnueli, H. Liang, M. Rozenberg, and R. Mittler, "Growth suppression, altered stomatal responses, and augmented induction of heat shock proteins in cytosolic ascorbate peroxidase (Apx1)deficient Arabidopsis plants," Plant Journal, vol. 34, no. 2, pp. 187-203, 2003.

[56] E. Kuniak and M. Sklodowska, "Ascorbate, glutathione and related enzymes in chloroplasts of tomato leaves infected by Botrytis cinerea," Plant Science, vol. 160, no. 4, pp. 723-731, 2001.

[57] U. H. Cho and N. H. Seo, "Oxidative stress in Arabidopsis thaliana exposed to cadmium is due to hydrogen peroxide accumulation," Plant Science, vol. 168, no. 1, pp. 113-120, 2005.

[58] J. A. Ryals, U. H. Neuenschwander, M. G. Willits, A. Molina, H. Y. Steiner, and M. D. Hunt, "Systemic acquired resistance," The Plant Cell, vol. 8, no. 10, pp. 1809-1819, 1996.

[59] J. Ebel and E. G. Cosio, "Elicitors of plant defense responses," International Review of Cytology, vol. 148, pp. 1-36, 1994.

[60] M. G. Hahn, "Microbial elicitors and their receptors in plants," Annual Review of Phytopathology, vol. 34, pp. 387-412, 1996.

[61] T. Nürnberger, "Signal perception in plant pathogen defense," Cellular and Molecular Life Science, vol. 55, pp. 167-182, 1999.

[62] T. Boller, "Chemoperception of microbial signals in plant cells," Annual Review of Plant Physiology and Plant Molecular Biology, vol. 46, pp. 189-214, 1995.

[63] J. Cohn, G. Sessa, and G. B. Martin, "Innate immunity in plants," Current Opinion in Immunology, vol. 13, no. 1, pp. 55-62, 2001.

[64] R. Luderer and M. H. A. J. Joosten, "Avirulence proteins of plant pathogens: determinants of victory and defeat," Molecular Plant Pathology, vol. 2, no. 6, pp. 355-364, 2001.

[65] Z. Nimchuk, L. Rohmer, J. H. Chang, and J. L. Dangl, "Knowing the dancer from the dance: R-gene products and their interactions with other proteins from host and pathogen," Current Opinion in Plant Biology, vol. 4, no. 4, pp. 288-294, 2001.

[66] T. Nürnberger and D. Scheel, "Signal transmission in the plant immune response," Trends in Plant Science, vol. 6, pp. 372-379, 2001. 
[67] B. M. Tyler, "Molecular basis of recognition between Phytophthora pathogens and their hosts," Annual Review of Phytopathology, vol. 40, pp. 137-167, 2002.

[68] N. Shibuya and E. Minami, "Oligosaccharide signalling for defence responses in plant," Physiological and Molecular Plant Pathology, vol. 59, no. 5, pp. 223-233, 2001.

[69] T. Nürnberger and F. Brunner, "Innate immunity in plants and animals: emerging parallels between the recognition of general elicitors and pathogen-associated molecular patterns," Current Opinion in Plant Biology, vol. 5, no. 4, pp. 318-324, 2002.

[70] P. Chen and Z. Li, "BTH systemic induction to defense related enzymes in wheat leaves," Acta Botanica Boreali-Occidentalia Sinica, vol. 26, no. 12, pp. 2468-2472, 2006.

[71] C. Bohland, T. Balkenhohl, G. Loers, I. Feussner, and H. J. Grambow, "Differential induction of lipoxygenase isoforms in wheat upon treatment with rust fungus elicitor, chitin oligosaccharides, chitosan, and methyl jasmonate," Plant Physiology, vol. 114, no. 2, pp. 679-685, 1997.

[72] M. V. B. Reddy, J. Arul, P. Angers, and L. Couture, "Chitosan treatment of wheat seeds induces resistance to Fusarium graminearum and improves seed quality," Journal of Agricultural and Food Chemistry, vol. 47, no. 3, pp. 1208-1216, 1999.

[73] N. Benhamou and R. R. Bélanger, "Induction of systemic resistance to Pythium damping-off in cucumber plants by benzothiadiazole: ultrastructure and cytochemistry of the host response," Plant Journal, vol. 14, no. 1, pp. 13-21, 1998.

[74] M. N. Brisset, S. Cesbron, S. V. Thomson, and J. P. Paulin, "Acibenzolar-S-methyl induces the accumulation of defenserelated enzymes in apple and protects from fire blight," European Journal of Plant Pathology, vol. 106, no. 6, pp. 529-536, 2000.

[75] L. G. Hjeljord, A. Stensvand, and A. Tronsmo, "Effect of temperature and nutrient stress on the capacity of commercial Trichoderma products to control Botrytis cinerea and Mucor piriformis in greenhouse strawberries," Biological Control, vol. 19, no. 2, pp. 149-160, 2000.

[76] W. S. Washington, S. Engleitner, G. Boontjes, and N. Shanmuganathan, "Effect of fungicides, seaweed extracts, tea tree oil, and fungal agents on fruit rot and yield in strawberry," Australian Journal of Experimental Agriculture, vol. 39, no. 4, pp. 487-494, 1999.

[77] M. Oostendorp, W. Kunz, B. Dietrich, and T. Staub, "Induced disease resistance in plants by chemicals," European Journal of Plant Pathology, vol. 107, no. 1, pp. 19-28, 2001.

[78] I. F. Kappers, A. Aharoni, T. W. J. M. van Herpen, L. L. P. Luckerhoff, M. Dicke, and H. J. Bouwmeester, "Genetic engineering of terpenoid metabolism attracts bodyguards to Arabidopsis," Science, vol. 309, no. 5743, pp. 2070-2072, 2005.

[79] G. M. Poppy and M. J. Wilkinson, Gene Flow from GM Plants-A Manual for Assessing, Measuring and Managing the Risks, Blackwell Publishing, Oxford, UK, 2005. 

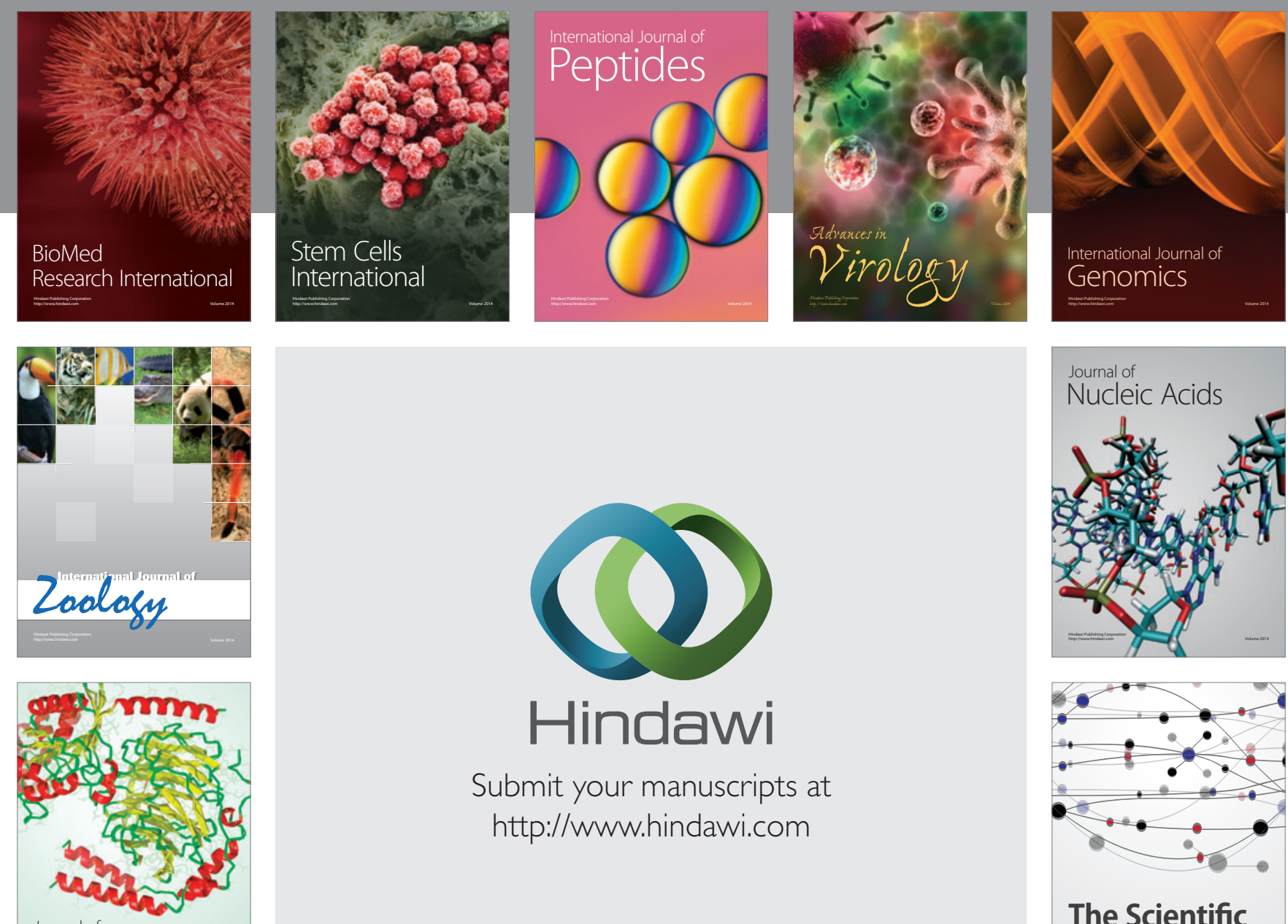

Submit your manuscripts at

http://www.hindawi.com

Journal of
Signal Transduction
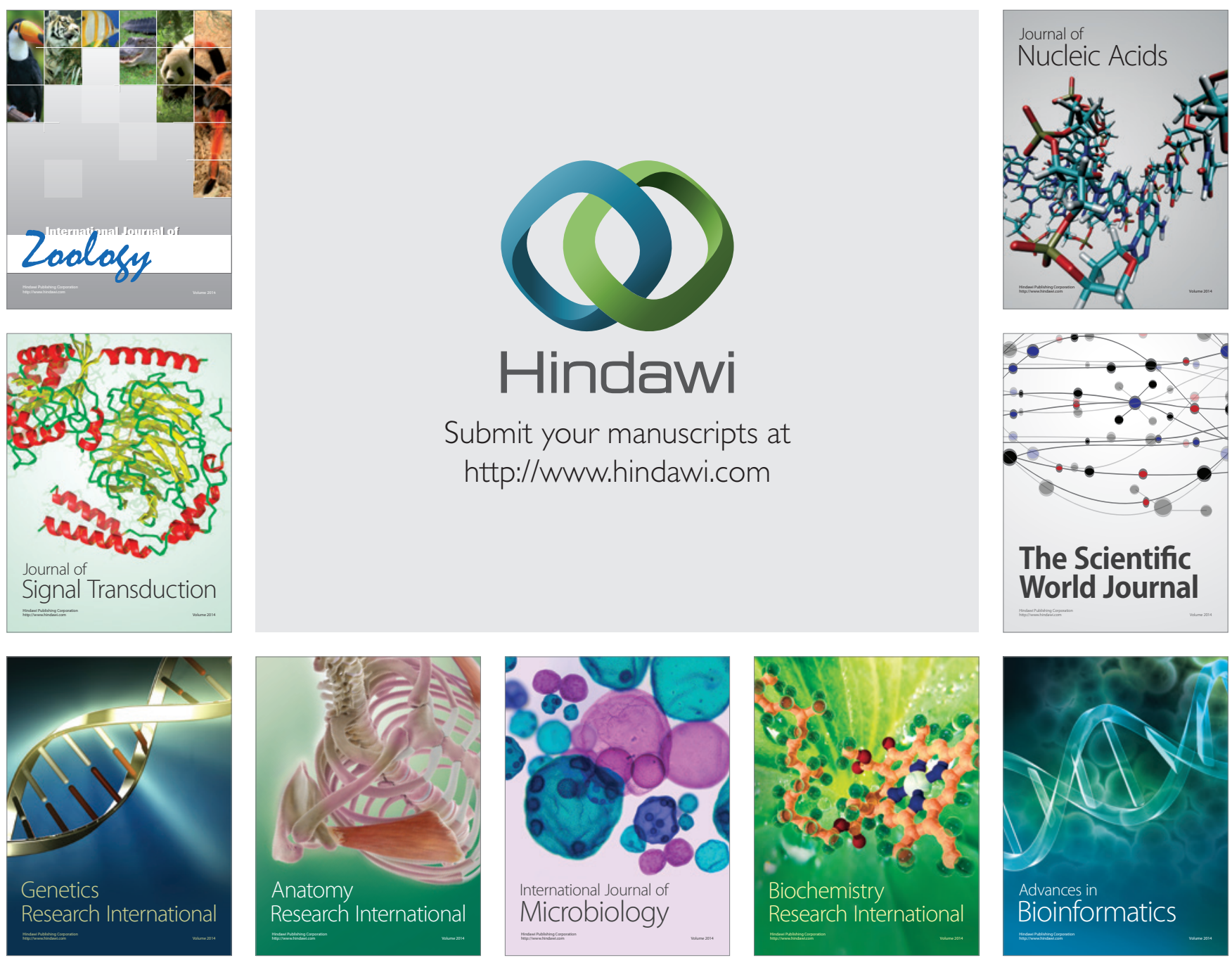

The Scientific World Journal
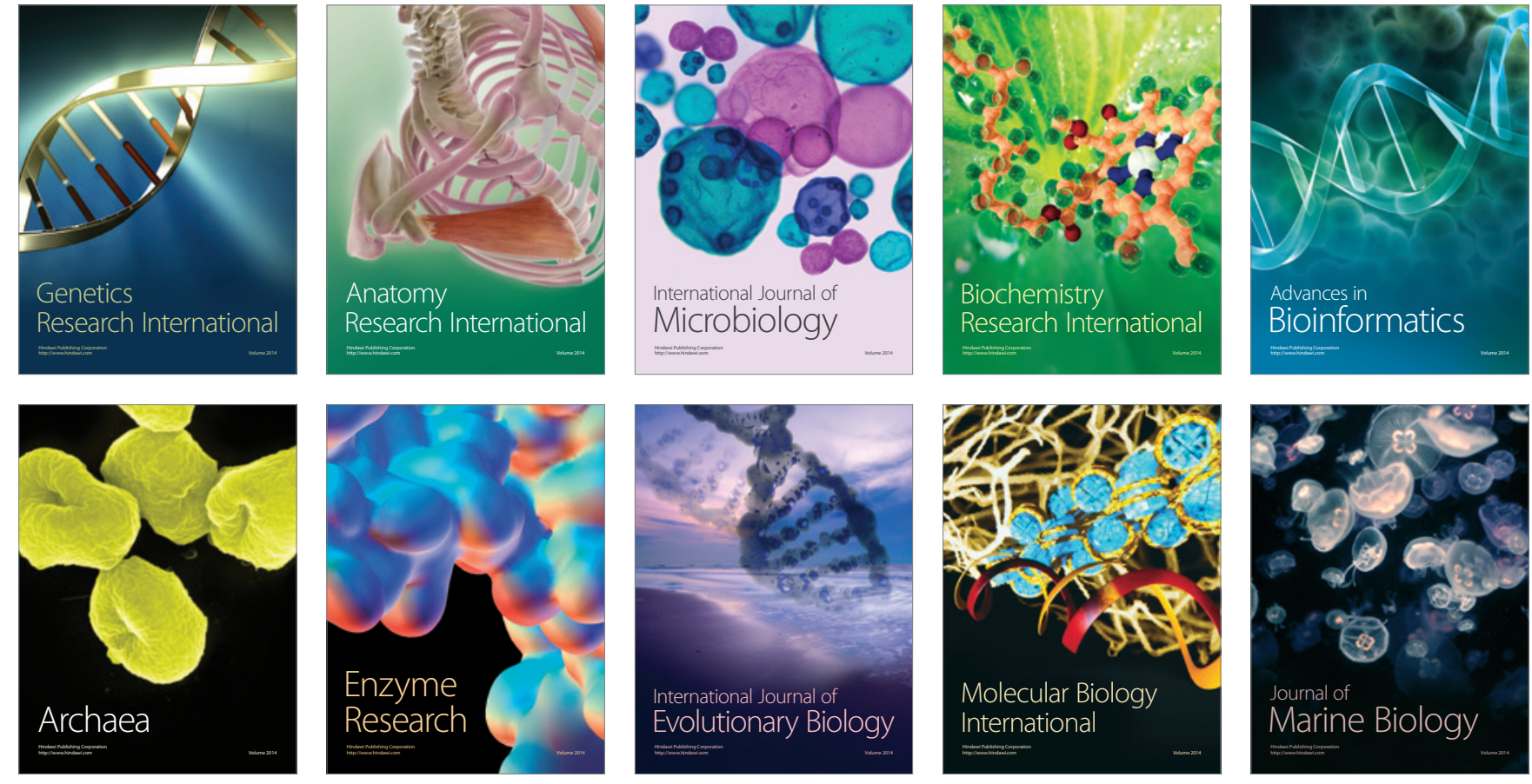